\title{
Rola nadwyżki operacyjnej w budowaniu stabilności finansowej i potencjalu inwestycyjnego jednostek samorządu terytorialnego
}

\section{THE ROLE OF THE OPERATING SURPLUS IN BUILDING THE FINANCIAL STABILITY AND INVESTMENT POTENTIAL OF LOCAL GOVERNMENT UNITS}

\begin{abstract}
Niniejsze opracowanie ma na celu ocenę poziomu nadwyżki operacyjnej jako wskaźnika determinujacego stabilność finansowq samorzqdów lokalnych oraz poznanie kwoty wydatków inwestycyjnych świadczacych o potencjale inwestycyjnym jednostki. Zastosowano nastepujace metody: analizę piśmiennictwa, analizę wskaźników budżetowych (dochody i wydatki bieżace, wydatki majatkowe, wynik operacyjny) oraz metody statystyki opisowej. Do analizy przyjęto dane finansowe wszystkich typów jednostek samorzadu terytorialnego w Polsce, a więc 16 województw, 314 powiatów i 2478 gmin za lata 2015-2017. Przeprowadzona analiza pozwoliła na częściowo pozytywne zweryfikowanie hipotezy zgodnie, z którq wynik operacyjny determinuje zarówno stabilność finansowq jak $i$ wyznacza poziom potencjału inwestycyjnego JST.
\end{abstract}

Słowa kluczowe: stabilność finansowa, potencjał finansowy, potencjał inwestycyjny, nadwyżka operacyjna.

JEL Codes: R50, R51, H72.

\section{Wstęp}

Współcześnie zarówno Europa jak i wiele innych wysoko rozwiniętych państw podąża w kierunku realizacji koncepcji zrównoważonego rozwoju, z którym wiąże się idea zrównoważonych finansów. Analiza elementów składowych procesu rozwoju zrównoważonego wskazuje, że jego realizacja uzależniona jest od zakresu zaangażowania systemu finansowego. Pojęcie zrównoważonych finansów należy do stosunkowo nowych i słabo rozpowszechnionych, lecz zyskujących na znaczeniu ${ }^{1}$. R. Shiller ${ }^{2}$ (noblista z 2013r.) wskazuje, że finanse należy definiować przede wszystkim jako metodę i formę zarządzania majątkiem społeczeństwa, która powinna przyczyniać się do wzrostu jego dobrobytu, co tylko potwierdza istotność i aktualność koncepcji zrównoważonych finansów.

\footnotetext{
${ }^{1}$ A. Alińska, S. Frydrych, E. Klein: Finanse w koncepcji zrównoważonego rozwoju. Kwartalnik Kolegium Ekonomiczno-Społecznego „Studia i Prace” Szkoły Głównej Handlowej, 2018, nr 1, s. 28.

${ }^{2}$ R. Shiller: Finance and the good society. Princeton University Press, Princeton 2012.
} 
Sytuacja finansowa samorządów lokalnych oraz stabilność usług publicznych ma wpływ na rozwój gospodarczy kraju, a także toczący się proces reform politycznych zmierzających do promowania wydajności jednostek sektora publicznego, ich zrównoważonych budżetów oraz stabilności finansowej ${ }^{3}$.

\section{Zrównoważone finanse i stabilność finansowa -konotacje teoretyczne}

$\mathrm{W}$ wielu opracowaniach prezentowane jest podejście stawiające na równi stabilność finansową ze stabilnością fiskalną, czyli zdolnością do wywiązywania się ze zobowiązań. W literaturze przedmiotu stabilność finansową określa się w ujęciu ogólnym jako stan, w którym system finansowy może pełnić swoje funkcje w sposób ciagły i efektywny, nawet w przypadku wystapienia nieoczekiwanych i niekorzystnych zaburzeń o znacznej skali oraz niskim prawdopodobieństwie wystapienia ${ }^{4}$. W podobnej konwencji wiążącej problematykę stabilności ze zdolnością funkcjonalną systemu określana jest stabilność fiskalna sektora publicznego i sektora finansów publicznych. Jest to więc zdolność jednostek organizacyjnych tworzących zakres wymienionych sektorów do świadczenia usług publicznych $\mathrm{w}$ chwili obecnej, bez uszczerbku dla możliwości ich świadczenia w przyszłości. Zdolność ta opiera się na możliwości wywiązywania się z bieżących zobowiązań finansowych, a w przyszłości utrzymywania jej bez konieczności powodowania ciagłego wzrostu zadłużenia (IFAC ${ }^{5}$ i CICA $^{67}$. Stabilność finansowa jest zatem zdolnością do finansowania usług publicznych bez narażania ich przyszłego świadczenia $\mathrm{w}$ związku $\mathrm{z}$ ryzykiem cięć wydatków lub podwyżek podatków. Jednostka sektora publicznego jest finansowo zrównoważona, gdy jest w stanie wygenerować wystarczające dochody, aby realizować swoje podstawowe funkcje i dostarczać usługi na akceptowalnym poziomie ${ }^{8}$. W opracowanych przez Międzynarodową Federację Księgowych (International Federation of Accounts - IFAC) Międzynarodowych Standardach Rachunkowości (International Accounting Standards Board - IASB) długoterminowa stabilność fiskalna jednostek sektora finansów publicznych jest rozpatrywana $\mathrm{w}$ trzech wymiarach: usług publicznych, dochodów publicznych i długu publicznego 9 (rysunek 1.).

\footnotetext{
${ }^{3}$ M. Pedro Rodríguez Bolívar, A. Navarro Galera, L. Alcaide Muñoz, M. Deseada López Subires: Analyzing Forces to the Financial Contribution of Local Governments to Sustainable Development, MDPI, Sustainability 2016, nr 8 (9), s. 3.

${ }^{4}$ Raport o stabilności systemu finansowego, Departament Stabilności Finansowej NBP. Warszawa 2018, s. 4.

${ }^{5}$ Reporting on the Long-Term Sustainability of a Public Sector Entity's Finances; IFAC, Canada 2012.

${ }^{6}$ Indicators of Financial Condition In Public Sector Statements of Recommended Practice (SORP), CICA, Toronto, ON, Canada 2009.

7 A. Navarro-Galera, M.P. Rodriquez-Bolivar, L. Alcaide-Munoz, M.D. Lopez-Subires, Measuring the financial sustainability and it's influential factors in local governments, „Applied Economics” 2016, vol. 48, nr 41, s. 3961-3975.

${ }^{8}$ Financial Management in a Local Government Association (LGA). Netherlands Ministry of Foreign Affairs, VNG International, 2014, s.10.

${ }^{9}$ Recomended Practice Guideline. Reporting on the Long-Term Sustainability of an Entity's Finances, International Public Sector Accounting Standards, International Federation of Accountants, New York 2015, s. 207.
} 


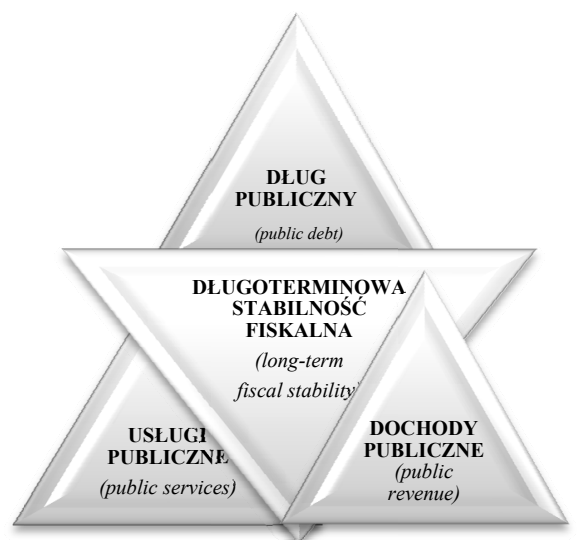

Rysunek 1. Wymiary długoterminowej stabilności fiskalnej jednostek sektora finansów publicznych Źródło: opracowanie własne na podstawie Proposed Recomended Practice Guideline. Reporting on the LongTerm Sustainability of a Public Sector Entity’s Finances; IFAC, Canada 2012.

Ocena stabilności finansowej jednostki samorządu terytorialnego (JST) jest ważnym zagadnieniem, ponieważ podmioty te są istotną częścią procesów gospodarczych. W Polsce samorząd jest nie tylko największym usługodawcą, ale także poważnym inwestorem. Zdaniem K. Kluzy ${ }^{10}$ inwestycje samorządowe uratowały polską gospodarkę od dotkliwych skutków kryzysu finansowego, ale znacznie pogorszyły własną kondycję finansową. A zatem sytuacja finansowa jednostek samorządu terytorialnego wpływa na rozwój innych dziedzin ich funkcjonowania i jest źródłem informacji o ich potencjale rozwoju gospodarczego, a jednocześnie pozwala kompleksowo oceniać działanie tych podmiotów.

Po transformacji ustrojowej samorządy uzyskały samodzielność finansową, która wpłynęła na ich rozwój w obszarze zarządzania finansami. Decentralizacja finansowa, ustrojowa, administracyjna wprowadziła swobodę w podejmowaniu decyzji finansowych i gospodarczych. Widoczną ułomnością funkcjonowania systemu finansowego sfery publicznej jest decentralizacja finansowa, która nie nadąża za decentralizacją zadań. Powszechnie znana jest zależność pomiędzy poziomem zasobów finansowych oraz stopniem realizacji zadań publicznych, a jakością życia zbiorowości lokalnej. Jednak delegowaniu zadań na poziom samorządu nie zawsze towarzyszy przekazywanie odpowiednich środków finansowych. Warto podkreślić, iż stabilność uwarunkowana jest właściwie skonstruowanym system finansowania JST. Można więc stwierdzić, iż z jednej strony źródłem słabości finansów samorządowych jest niedobór posiadanych środków finansowych, a $\mathrm{z}$ drugiej brak racjonalnego systemu gospodarowania nimi zgodnie z ideą zrównoważonych finansów.

$\mathrm{W}$ polskich regulacjach prawnych nie zawarto dosłownej i wyczerpującej definicji stabilności finansowej, jednak ustawa o finansach publicznych zawiera pewne odniesienia do poszczególnych elementów pozwalających zachować stabilność finansową JST (tabela 1).

${ }^{10}$ Dochody jednostek samorządu terytorialnego 2004-2012. Perspektywa 2013-2020. Senat RP, Związek Miast Polskich, Warszawa 2013. 
Tabela 1. Elementy pozwalające zachować stabilność finansową JST

\begin{tabular}{|l|c|}
\hline \multicolumn{1}{|c|}{ Wyszczególnienie } & $\begin{array}{c}\text { Zapis ustawy o finansach } \\
\text { publicznych }\end{array}$ \\
\hline kwestia zachowania równowagi budżetowej & art. 242 \\
\hline zasady sfinansowania deficytu budżetowego & art. 217 \\
\hline kwestia stanowienia systemu rezerw & art. 222 \\
\hline prawidłowość prowadzenia gospodarki finansowej JST & art. 254 \\
\hline działania zmierzających do zachowania stabilności finansowej & art. 86 , art. 260 \\
\hline indywidualny wskaźnik zadłużenia (IWZ) - ograniczenie zadłużenia JST & art. 243 \\
\hline
\end{tabular}

Źródło: opracowanie własne na podstawie ustawy z dnia 27 sierpnia 2009r. o finansach publicznych (Dz. U. $2009 \mathrm{Nr} 157$, poz. 1240)

W literaturze pojawiają się próby określenia stabilności finansowej JST jako stan pozwalający na wypełnianie funkcji JST, umożliwiający realizację transakcji dotyczących zadań JST z gwarancją, że nie wpłyną w sposób negatywny na budżet. ponadto stabilność wiąże się z efektywną alokacją zasobów finansowych i rzeczowych oraz skuteczną identyfikacją i zarządzaniem ryzykiem. Reasumując stabilność ta określa się jako stan, w którym władze samorządowe są w stanie zapewnić dostosowany do potrzeb wspólnoty terytorialnej zakres odpowiedniej jakości usług publicznych, jak również stymulować jej przyszły rozwój społeczno-gospodarczy. Jednocześnie akcentuje się fakt, że analizowana kategoria ma szerszy wymiar niż tylko kwestie zagwarantowania bieżącej płynności, czy też długoterminowej wypłacalności jednostek samorządowych $^{11}$. Stabilność finansowa JST łączona jest także $\mathrm{z}$ zagadnieniem bezpieczeństwa finansowego objawiającego się zdolnością do wywiązywania się ze zobowiązań, sprawnością dochodową, efektywnością realizacji zadań, zdolnością do realizacji polityki rozwojowej ${ }^{12}$. W przywołanym kontekście bezpieczeństwa finansowego stan stabilności finansowej JST utożsamia się z sytuacją, w której wszelkie zakłócenia pochodzące z rynku nie spowodują utraty zdolności do wywiązywania się ze zobowiązań, a realizacja zadań zostanie zapewniona na dotychczasowym poziomie jakościowym i ilościowym. Praktyka organów samorządowych weryfikuje wspomniane podejście teoretyczne poprzez konieczność podejmowania decyzji uwzględniających występowanie różnych czynników destabilizujących bezpieczeństwo finansowe.

Nawiązując do wymienionych wymiarów długoterminowej stabilności fiskalnej, w przypadku JST rozumiana jest ona jako długoterminowa zdolność do:

- finansowania zarówno zadań własnych, jak i zleconych przez administrację rządową (wymiar dochodowy),

- $\quad$ świadczenia lokalnych usług publicznych w sposób ciagły i efektywny (wymiar usługowy),

- regulowania zobowiązań finansowych (wymiar zadłużeniowy) ${ }^{13}$.

\footnotetext{
${ }^{11}$ K. Wójtowicz: Podział zadań publicznych między państwo a samorząd a problem zapewnienia stabilności fiskalnej jednostek samorządu terytorialnego. „Nierówności Społeczne a Wzrost Gospodarczy” 2014, nr 40 (4), s. 303-312.

${ }_{12}^{12}$ B. Filipiak: Wykorzystanie statystyki publicznej..., op. cit., 13-33.

${ }^{13}$ M. Poniatowicz: Stabilność finansowa jednostek samorządu terytorialnego w aspekcie nowej perspektywy finansowej Unii Europejskiej i zmian w systemie dochodów samorządowych. „Ekonomiczne Problemy Usług” 2016, nr 125, s.7-23; L. Klank, Stabilność finansowa jednostek samorządu terytorialnego, „Przedsiębiorczość i Zarządzanie" 2014, t. XV, z 9, cz. III, s. 72.
} 
W dalszych rozważaniach uwzględniono wymiar usługowy stabilności fiskalnej JST i w związku z tym analizie poddano potencjał jednostki samorządowej $\mathrm{w}$ tym zakresie.

W odniesieniu do potencjału inwestycyjnego rozważania należy rozpocząć od właściwego rozumienia potencjału ekonomicznego JST definiowanego jako stan finansów lokalnych uwzględniający stopień rozwoju ekonomicznego jednostek samorządowych ${ }^{14}$. Analiza pojęcia potencjału ekonomicznego wskazuje, że potencjał finansowy stanowi jego szczególną składową i oddziałuje na kształtowanie pozostałych jego elementów. Większość autorów potencjał finansowy definiuje jako pewną zdolność JST do (M. Miszczuk ${ }^{15}$ i M. Wosiek ${ }^{16}$ M. Szpak ${ }^{17}$ ):

- pozyskiwania zasobów pieniężnych i ich efektywnego wydatkowania,

- realizowania zamierzeń inwestycyjnych oraz zaciagania i obsługi długu. Posiadanie zdolności kredytowej, pozwalającej na spłatę wszystkich zobowiązań wraz $\mathrm{z}$ należnymi odsetkami $\mathrm{w}$ terminie, jest jednym $\mathrm{z}$ ważniejszych elementów tworzących potencjał finansowy, a to łączy pojęcie potencjału finansowego z podstawową definicją stabilności finansowej JST,

- racjonalnego zarządzania sferą dóbr publicznych przez JST różnego szczebla. Zdolność tą określa m.in. poziom dochodów w przeliczeniu na jednego mieszkańca oraz ich struktura, zwłaszcza udział tzw. dochodów własnych, określających stopień finansowej samodzielności samorzą̧ów.

Zdaniem B. Hok $^{18}$ potencjał finansowy determinuje procesy związane z gromadzeniem i wydatkowaniem środków publicznych. Wielkość zasobów finansowych wyznacza granice możliwości realizacji zadań publicznych, oddziałując, na jakość życia zbiorowości lokalnej. Najbardziej kompleksowe podejście do definicji potencjału finansowego to podejście zasobowe, uwzględniające zarówno czynnik czasu jak i przestrzeni, w której zachodzą procesy będące udziałem JST. Zgodnie z tą koncepcją potencjał finansowy to:

- zasoby finansowe (kapitał, wierzytelności, gotówka w kasie i na rachunku bankowym),

- potencjalne możliwości kreowania zasobów finansowych poprzez aktywną politykę prowadzoną przez władze samorządowe (np. politykę dochodową czy wydatkową pobudzającą przedsiębiorczość lub dająca możliwość uzyskiwania dochodów z zainwestowanych środków),

\footnotetext{
14 B. Filipiak: Podatkowe czynniki kształtujące potencjał finansowy jednostek samorządu terytorialnego, „Finanse, Rynki Finansowe, Ubezpieczenia” 2016, nr 1(79), s. 644.

${ }_{15}$ M. Miszczuk: Czynniki różnicujące potencjał finansowy gmin - próba typologii na przykładzie województwa lubelskiego, [w:] Gospodarka lokalna i regionalna w teorii i praktyce, (red.) R. Brol. Wydawnictwo Akademii Ekonomicznej im. Oskara Langego, Wrocław 2004.

${ }^{16}$ M. Wosiek: Regionalne zróżnicowanie sytuacji finansowej gmin w warunkach dysproporcji rozwojowych w Polsce. „Nierówności społeczne a wzrost gospodarczy”, Zeszyt Naukowy Uniwersytetu Rzeszowskiego 2013, nr 34, s. 145.

${ }^{17}$ M. Szpak: Etap 7. Określenie bezpiecznego dla miasta poziomu zadłużenia, [w:] Wieloletnie planowanie finansowe: ocena zdolności kredytowej w gminie, najtańszy pieniądz we właściwym czasie, (red.) K.S. Cichocki. Wyd. MUNICIPIUM, Warszawa 2001.

18 B. Hok: Wybrane czynniki finansowe do oceny zamożności jednostek samorządu terytorialnego na przykładzie gmin wiejskich i miejsko-wiejskich województwa zachodniopomorskiego, „Zeszyty Naukowe Wydziału Nauk Ekonomicznych Politechniki Koszalińskiej” 2016, nr 20, cz. 1, s. 111-127.
} 
- możliwości pasywnego kreowania zasobów finansowych (np. potencjalne możliwości zaciągania zobowiązań dłużnych i zobowiązań niezaliczanych do długu) ${ }^{19}$.

Jednostki samorządowe $\mathrm{w}$ ramach przypisanych im zadań własnych realizują inwestycje, które przyczyniają się do przyspieszenia tempa rozwoju lokalnego i regionalnego. Wśród wachlarza czynników ${ }^{20}$ wpływających na planowanie i prowadzenie inwestycji samorządowych najważniejsze są te zaliczane do grupy determinantów finansowych związanych z sytuacją budżetową samorządów. Finanse uznawane są więc za kluczowy element funkcjonowania JST oraz podstawowy wyznacznik realności i powodzenia każdej inwestycji. Należy zatem ustalić znaczenie potencjału inwestycyjnego (rozwojowego) JST, który rozumiany jest jako zdolność danej jednostki do gromadzenia środków finansowych na realizację zadań inwestycyjnych ${ }^{21}$.

Wyróżnia się trzy stopnie potencjału inwestycyjnego ${ }^{22}$ :

1. potencjał inwestycyjny pierwszego stopnia - oznacza część dochodów bieżących pozostających po sfinansowaniu wydatków bieżących i rocznej spłacie zadłużenia. Istotne jest, że roczna spłata zadłużenia traktowana jako rozchód obejmuje wyłącznie spłatę rat kapitałowych wcześniej zaciąnniętych kredytów, pożyczek oraz wykup papierów wartościowych.

2. potencjał inwestycyjny drugiego stopnia - oznacza część dochodów bieżących i majątkowych budżetu pozostających do dyspozycji po sfinansowaniu wydatków bieżących i spłacie zadłużenia.

3. potencjał inwestycyjny trzeciego stopnia - uwzględnia również środki z innych źródeł, np. dofinansowanie realizacji zadań ze środków UE. Możliwość korzystania ze środków unijnych na inwestycje powoduje wzrost potencjału inwestycyjnego samorządów przez pryzmat wyższych dochodów majątkowych.

Zagadnieniem łączącym rozważane dotychczas kwestie stabilności finansowej oraz potencjału inwestycyjnego jest wynik finansowy jednostki samorządowej. W ocenie stabilności finansowej i potencjału inwestycyjnego JST istotne jest określenie poziomu nadwyżki operacyjnej stanowiącej dodatnią różnicę między dochodami bieżącymi, a wydatkami bieżącymi ${ }^{23}$. Podział dochodów i wydatków na bieżące i majątkowe pełni fundamentalną rolę w finansach JST. Warto podkreślić, że w kasowym ujęciu budżetu za dochody i wydatki uznaje się jedynie rzeczywiste płatności dokonane w roku budżetowym. Przy określaniu salda operacyjnego nie bierze się pod uwagę operacji finansowych w odniesieniu, do których w danym okresie nie nastapił kasowy przepływ środków finansowych, a które mogą w istotny sposób determinować przyszłą stabilność

\footnotetext{
${ }^{19}$ B. Filipiak, M. Tarczyńska-Łuniewska: Potencjał jednostki samorządu terytorialnego - próba systematyzacji pojęciowej i metodycznej, „Finanse Komunalne” 2016, nr 1-2, s. 643-653.

20 M. Dworakowska: Determinanty rozwoju aktywności inwestycyjnej miast na prawach powiatu, [w:] Instrumenty zarządzania finansami jednostek samorządu terytorialnego, (red.) D. Wyszkowska, Wydawnictwo Uniwersytetu w Białymstoku, Białystok 2013, s. 122-130.

${ }^{21}$ M. Mackiewicz, E. Malinowska-Misiąg, W. Misiąg, M. Tomalak: Ramy finansowe strategii rozwoju województw na lata 2007-2013, Instytut Badań nad Gospodarką Rynkową, Warszawa 2006, s. 8.

${ }^{22}$ T. Lubińska, S. Franek, M. Będzieszak: Potencjał dochodowy samorządu w Polsce, Difin, Warszawa 2008.

23 Ministerstwo Finansów: Wskaźniki do oceny sytuacji finansowej jednostek samorządu terytorialnego w latach 2014-2016, Warszawa 2017, www.finanse.mf.gov.pl/documents/766655/6146149/I-II+_Wsk+20142016_opis.pdf (dostęp 10.01.2019r.)
} 
finansową ${ }^{24}$. Od 2010r. istnieje wymóg prawny uniemożliwiający uchwalenie budżetu z ujemnym wynikiem finansowym spowodowanym zbyt wysokimi wydatkami bieżącymi. Saldo bieżące budżetu nie może być ujemne, co podkreśla, iż zadłużenie zawsze powinno wiązać się z działalnością inwestycyjną, a nie bieżącą (tzw. złota zasada finansowania). Istota zrównoważonego budżetu operacyjnego oparta jest na zasadzie, że deficyt budżetowy może wystąpić jedynie w części majątkowej budżetu. Racjonalność i przejrzystość zarządzania finansami, wynikająca z art. 242 ustawy o finansach publicznych, ma na celu ograniczenie nadmiernych wydatków bieżących jak również utrzymanie wydatków majątkowych na odpowiednim poziomie. ${ }^{25}$

Wynik operacyjny stanowi najbardziej syntetyczną miarę sytuacji finansoweje ${ }^{26}$, bowiem pozwala ustalić, czy jednostka samorządu terytorialnego jest $\mathrm{w}$ stanie pokryć wydatki bieżące dochodami bieżącymi, a także czy istnieją możliwości sfinansowania rozwoju JST. Finansowy wynik operacyjny samorządu lokalnego wskazuje, czy u podstaw zaplanowanych kosztów operacyjnych tj. wydatków bieżących leżą bieżące dochody. Samorządy lokalne muszą generować dochód operacyjny wystarczający do zrównoważenia kosztów (wydatków) ich działalności w krótkim okresie. Wysokie dochody nie przesądzają o dobrej kondycji finansów JST, gdyż takie czynniki jak: gęstość zaludnienia, struktura demograficzna, mogą być przyczyną wysokich wydatków budżetowych. Decydująca rola nadwyżki operacyjnej polega na dostarczaniu informacji o wysokości środków, które pozostają po sfinansowaniu najważniejszych wydatków wynikających z obowiązkowych zadań $\mathrm{JST}^{27}$. Ponadto warto podkreślić, iż w wydatkach bieżących w dziale 757 zawarte są koszty obsługi długu. Dodatni wynik bieżący może powiększyć wartość wydatków majątkowych, a więc informuje o możliwościach inwestycyjnych jednostki. Zdolność wypracowywania długookresowych nadwyżek kreuje tempo procesów rozwojowych JST. Określa stopień w jakim JST może zaciągać nowe zobowiązania na przedsięwzięcia inwestycyjne ${ }^{28}$, ponieważ poziom nadwyżki operacyjnej wyznacza granice zadłużania się JST i wskazuje ile środków jednostka może przeznaczyć na spłatę zobowiązań. Poziom nadwyżki operacyjnej określa więc, czy samorząd lokalny jest stabilny finansowo i czy będzie w stanie bieżąco świadczyć usługi publiczne.

Wzrost wartości nadwyżki operacyjnej należy utożsamiać z pozytywnym objawem, ponieważ stanowi ona swoisty barometr kondycji finansowej JST. Wskaźnik nadwyżki operacyjnej stanowi zatem ważny punkt wyjścia do podejmowania decyzji finansowych dotyczących zarówno kwestii zarządzania długiem jak i aktywności inwestycyjnej jednostki ${ }^{29}$. Nadwyżka operacyjna nie obejmuje jednak dochodów i wydatków o charakterze majątkowym, które mogą mieć bardzo istotny wpływ na kondycję

\footnotetext{
24 M. Wiewióra: Wpływ nadwyżki operacyjnej budżetu na kondycję finansową jednostki samorządu terytorialnego, „Samorząd Terytorialny” 2008, nr 11, s. 12-18.

25 M. Wojciechowski: Kierunki racjonalizacji gospodarki finansowej samorządu terytorialnego, Zeszyty Naukowe Wyższej Szkoły Bankowej w Poznaniu 2017, t.73, nr 2, s. 248.

${ }^{26}$ P. Swianiewicz, Nadwyżka operacyjna, www.wspolnota.org.pl/index.php?, (dostepp: 24.09.2018r.)

${ }^{27}$ Wiewióra M., 2008, http://www.samorzad.pap.pl/palio/html.run?_Instance=cms_samorzad.pap.pl\&_Pa 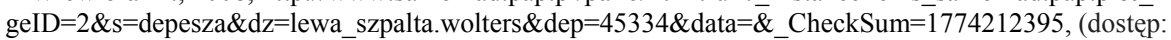 08.12.2018r.)

${ }^{28}$ Ocena efektywności zarządzania długiem lokalnym w Polsce na przykładzie miast na prawach powiatu, Zeszyty Naukowe Polskiego Towarzystwa Ekonomicznego w Zielonej Górze 2018, nr 9, s. 52

${ }^{29}$ Improving Financial Sustainability for Local Government, Walga, www.walga.asn.au (dostęp 17.01.2019r.)
} 
finansową JST, a w efekcie na ich bezpieczeństwo finansowe. Nie uwzględnia także zwrotnych przepływów finansowych związanych z zaciąganiem i spłatą zadłużenia, które pod pewnymi warunkami mogą stabilizować sytuację finansowa.

Metodologia wyznaczania własnego potencjału finansowego $\mathrm{JST}^{30}$ koncentruje się także na sposobie jego szacowania poprzez ustalenie kwot, jakie w badanym okresie jednostki mogą przeznaczyć na realizację zadań rozwojowych, czyli ustalenie jaka część otrzymywanych dochodów może zostać przeznaczona na sfinansowanie wydatków inwestycyjnych obejmujących m.in. wszystkie wydatki majątkowe $\mathrm{z}$ wyłączeniem inwestycji odtworzeniowych oraz wydatki bieżące na przedsięwzięcia, wykraczające poza obligatoryjne zadania.

\section{Material i metodyka}

Do analizy przyjęto dane finansowe wszystkich typów jednostek samorządu terytorialnego w Polsce, a więc 16 województw, 314 powiatów i 2478 gmin (302 gminy miejskie w tym 66 miast na prawach powiatu, 621 miejsko-wiejskich oraz 1555 wiejskich) za lata 2014-2017.

Dokonano przeglądu literatury przedmiotu i ustalono, iż potencjał finansowy JST może być mierzony $\mathrm{z}$ uwzględnieniem różnych podejść metodycznych, a więc: koncepcji pomiaru własnego potencjału finansowego, jako składowej całkowitego potencjału finansowego, koncepcji pomiaru opartej na nadwyżce operacyjnej, koncepcji potencjału inwestycyjnego dającego podstawę do rozwoju JST, koncepcji potencjału inwestycyjnego jako pochodnej atrakcyjność inwestycyjnej JST, koncepcji wielowymiarowego podejścia do pomiaru potencjału finansowego ${ }^{31}$.

W niniejszym opracowaniu, oceny stabilności finansowej dokonano na podstawie wartości wyniku operacyjnego budżetu w ujęciu realnym w danym roku budżetowym dla wszystkich JST. Uznano, że stabilność ta zostaje zachowana w sytuacji, gdy jest on dodatni. Przyjęta metodologia szacowania poziomu stabilnych bieżących dochodów oraz wydatków pozwala zdefiniować własny potencjał finansowy JST przez pryzmat poziomu nadwyżki operacyjnej. Choć wartość nadwyżek operacyjnych wydaje się być dość wygodnym i jednocześnie stosunkowo prostym w interpretacji sposobem pomiaru stabilności finansowej JST, to jednak nie jest on pozbawiony pewnych mankamentów. W przeprowadzonych badaniach dokonano także oceny potencjału finansowego JST w oparciu o poziom salda operacyjnego budżetu oraz wartość poniesionych wydatków majątkowych będących przejawem istniejącego potencjału inwestycyjnego. Potencjał inwestycyjny jest związany z nadwyżką operacyjnă, gdyż oznacza ona wolne środki JST po sfinansowaniu wszelkich wydatków bieżących i po spłacie rat kredytów, pożyczek oraz wykupie papierów wartościowych uwidocznionych $\mathrm{w}$ rozchodach ${ }^{32}$. Podkreślić należy, że własny potencjał inwestycyjny uwzględnia zasoby finansowe zgromadzone

\footnotetext{
${ }^{30}$ Metoda opracowana przez Instytut Badań nad Gospodarką Rynkową.

${ }^{31}$ B. Filipiak: Podatkowe czynniki kształtujące..., op. cit., s. 645.

${ }^{32}$ E. Gubernat-Ulatowski: Potencjał finansowy i inwestycyjny a aktywność inwestycyjna jednostek samorządu terytorialnego, „Studia Ekonomiczne” Zeszyty Naukowe Uniwersytetu Ekonomicznego w Katowicach 2016, nr 294, s. 50-52.
} 
w budżetach JST wyłączając zaciagganie nowego długu ${ }^{33}$. Ponadto przeanalizowano poziom wydatków inwestycyjnych, aby móc ustalić czy uzyskana nadwyżka operacyjna stanowiła źródło finansowania działań prorozwojowych.

\section{Wyniki badań}

Analizie poddano ogólną oraz średnią wartość nadwyżki operacyjnej osiagniętej przez JST poszczególnych typów w latach 2014-2017 (wykres 1 i 2).

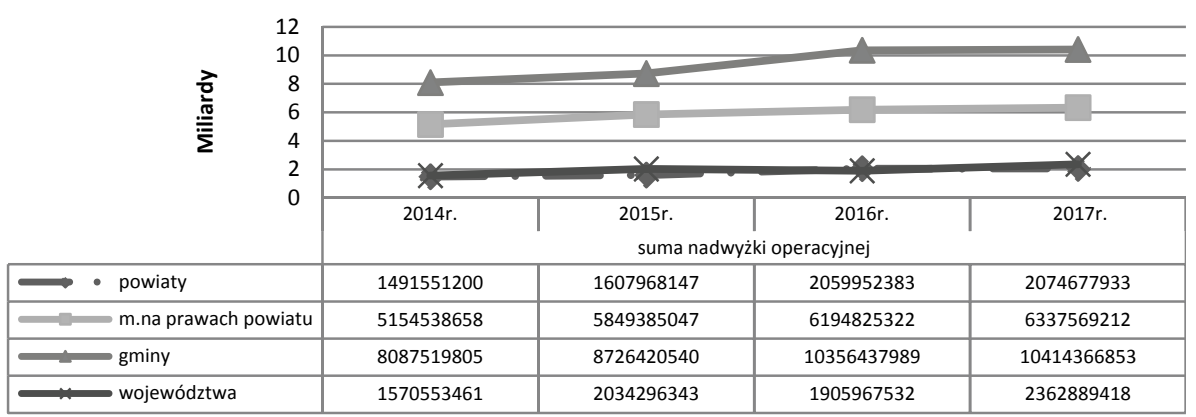

Wykres 1. Ogólna wartość nadwyżki operacyjnej według typu jednostki samorządu terytorialnego w latach 2014-2017 (mln zł)

Źródło: opracowanie własne na podstawie Informacji o nadwyżce operacyjnej jednostek samorządu terytorialnego w latach 2014 - 2016 oraz 2015 - 2017, Ministerstwo Finansów.

We wszystkich typach jednostek odnotowano wzrost ogólnej wartości nadwyżki operacyjnej, jednak najbardziej dynamiczny jej wzrost zauważono w przypadku gmin oraz województw. Istotne jest także zrelatywizowanie wartości nadwyżki operacyjnej przepadającej na jedną jednostkę samorządową w danej kategorii, dlatego obliczono jej wartość średnią w każdym typie JST (wykres 2).

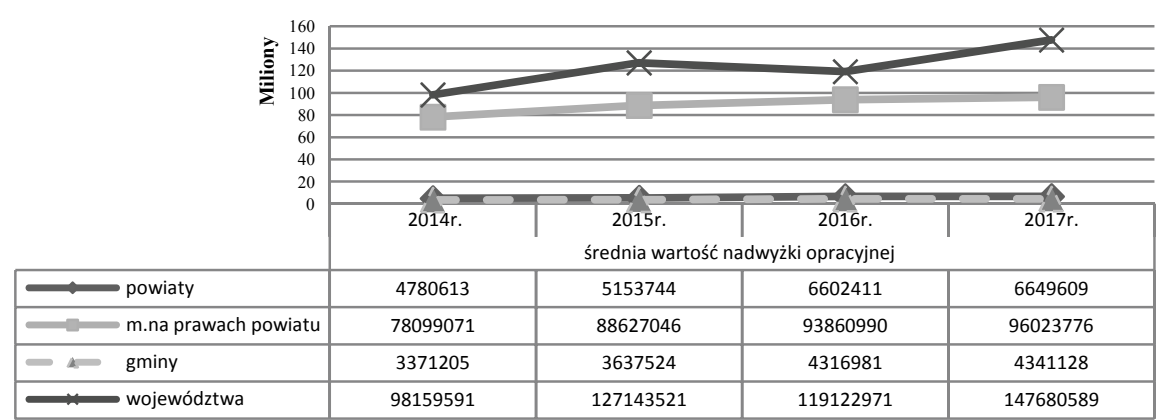

Wykres 2. Średnia wartość nadwyżki operacyjnej według typów jednostek samorządu terytorialnego w latach 2014-2017 (mln zł)

Źródło: opracowanie własne na podstawie Informacji o nadwyżce operacyjnej jednostek samorządu terytorialnego w latach 2014 - 2016 oraz 2015 - 2017, Ministerstwo Finansów.

${ }^{33}$ M. Jastrzębska: Polityka budżetowa jednostek samorządu terytorialnego, Wyd. Uniwersytetu Gdańskiego, Gdańsk 2005, s. 97-100. 
Najwyższą średnią wartość nadwyżki operacyjnej oraz najbardziej dynamiczny jej wzrost odnotowano w przypadku województw oraz miast na prawach powiatu. Uzyskane wyniki wskazuja, iż gminy i powiaty osiagały najniższą wartość dodatniego wyniku w budżecie operacyjnym przypadającą na jedną jednostkę. Ponadto gminy odnotowały najniższą średnią wartość nadwyżki operacyjnej oraz najmniej dynamiczną jej zmianę w latach 2014- 2017. Tak niski wynik sugeruje, że uśredniając wartość nadwyżki operacyjnej będącej w dyspozycji jednostek samorządowych to właśnie gminy uzyskały najmniej środków, co znacznie ograniczało stopień w jakim mogły zaciagać nowe zobowiązania i realizować nowe przedsięwzięcia inwestycyjne.

W kolejnym etapie podzielono jednostki w zależności od poziomu osiągniętej nadwyżki operacyjnej w każdym typie JST. Rozważania rozpoczęto od poziomu gmin, gdyż są one podstawową jednostką samorządu terytorialnego w Polsce (wykres 3).

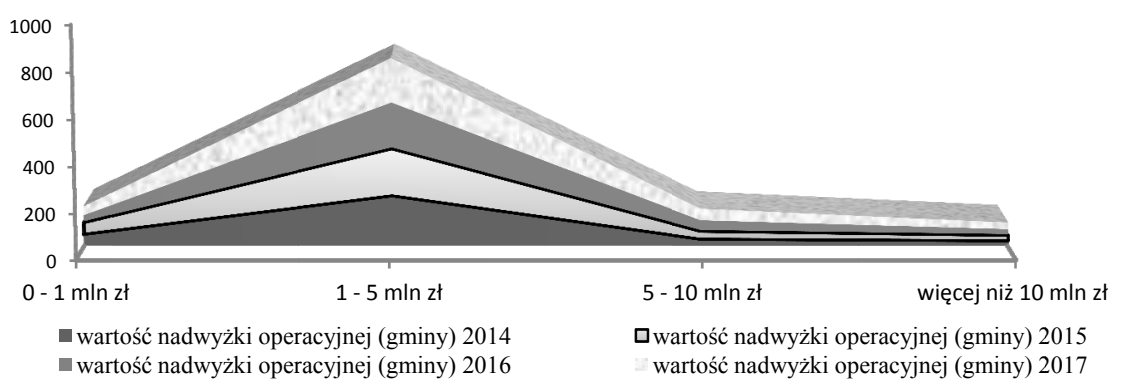

Wykres 3. Poziom nadwyżki operacyjnej osiągniętej przez gminy w latach 2014-2017 (mln zł)

Źródło: opracowanie własne na podstawie Informacji o nadwyżce operacyjnej jednostek samorządu terytorialnego w latach 2014 - 2016 oraz 2015 - 2017, Ministerstwo Finansów.

W analizowanym okresie największą grupę stanowiły gminy, które wypracowały nadwyżkę operacyjną o wartości od 1 do $5 \mathrm{mln}$ zł, choć liczba tych jednostek zmniejszyła się z 216 w 2014r. do 192 w 2017r. Odnotowano także spadek liczby gmin z nadwyżką nie przekraczającą $1 \mathrm{mln}$ zł o 9 jednostek, przy jednoczesnym zwiększeniu o 45\% liczebności grupy gmin z najwyższą wartością nadwyżki (powyżej $10 \mathrm{mln}$ zł). Tego typu zmiana sugeruje, iż stabilność finansowa mierzona poziomem nadwyżki operacyjnej ulega poprawie, a więc gminy zyskują stan, w którym usługi publiczne mogą być świadczone w przyszłości na niezmienionym poziomie. Kolejnym typem jednostek, w których badaniu poddano poziom osiągniętej nadwyżki operacyjnej były powiaty (wykres 4). 


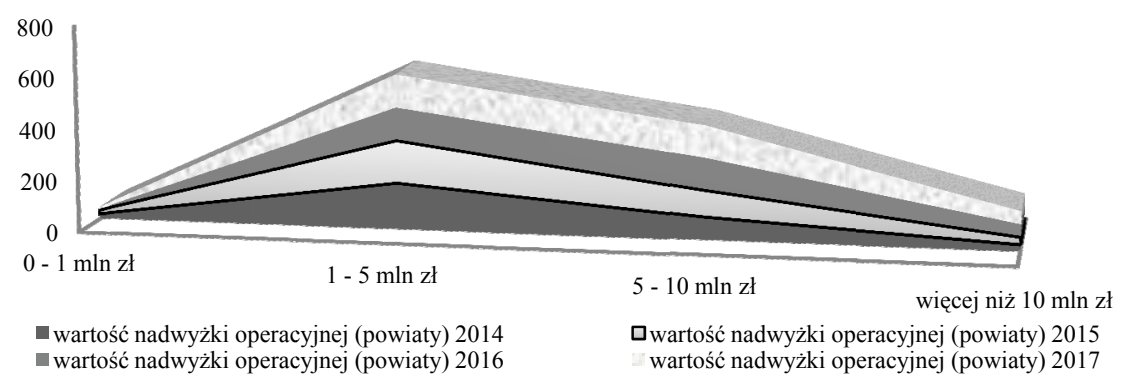

Wykres 4. Poziom nadwyżki operacyjnej osiagniętej przez powiaty w latach 2014-2017 (mln zł)Źródło: opracowanie własne na podstawie Informacji o nadwyżce operacyjnej jednostek samorządu terytorialnego w latach 2014 - 2016 oraz 2015 - 2017, Ministerstwo Finansów.

W przypadku powiatów także zaobserwowano dwukrotny wzrost liczby jednostek, które osiagnęły najwyższą wartość nadwyżki operacyjnej wynoszącej więcej niż $10 \mathrm{mln}$ zł i jednoczesny spadek o 55\% liczby jednostek o najniższej wartości nadwyżki nie przekraczającej poziomu $1 \mathrm{mln}$ zł (z 18 powiatów w 2014r. do 8 powiatów w 2017r.). Uzyskane wyniki świadczą, o tym iż stabilność finansowa tych jednostek także uległa poprawie, a zatem ich potencjał inwestycyjny powinien ulec zwiększeniu.

Miasta na prawach powiatu oraz województwa osiagnęły znacznie większy poziom nadwyżki operacyjnej, w związku z tym przyjęto wyższe przedziały jej wartości, co prezentują wykresy 5 i 6 .

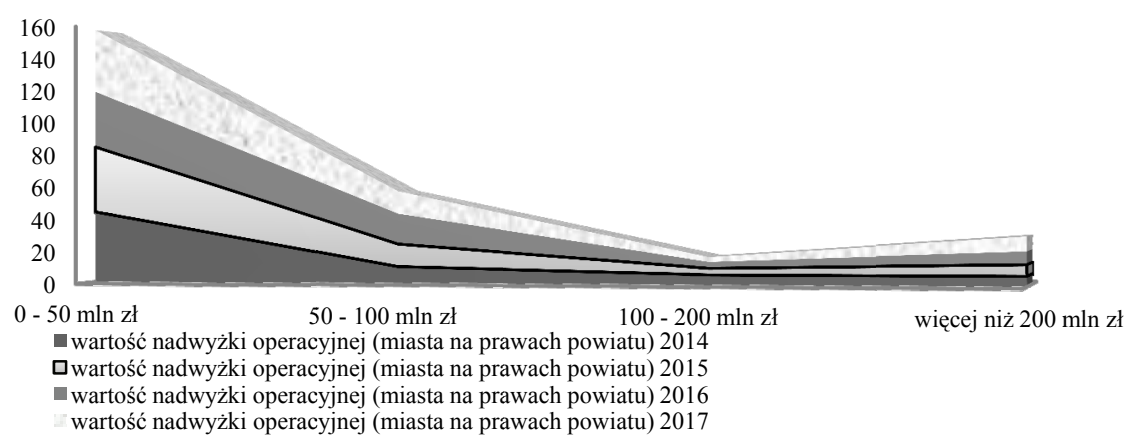

Wykres 5.Poziom nadwyżki operacyjnej w miastach na prawach powiatu w latach 2014-2017(mln zł)

Źródło: opracowanie własne na podstawie Informacji o nadwyżce operacyjnej jednostek samorządu terytorialnego w latach 2014 - 2016 oraz 2015 - 2017, Ministerstwo Finansów. 


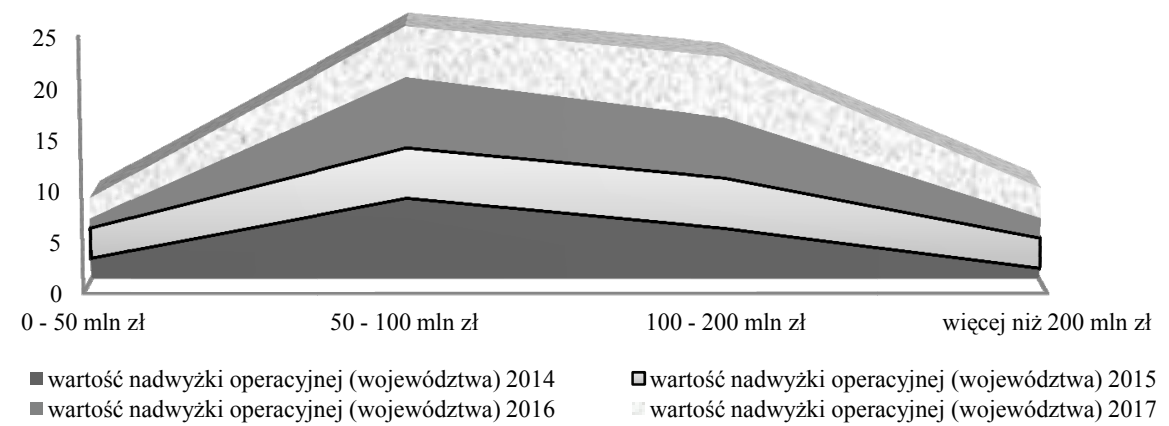

Wykres 6. Poziom nadwyżki operacyjnej osiągniętej przez województwa w latach 2014-2017(mln zł) Źródło: opracowanie własne na podstawie Informacji o nadwyżce operacyjnej jednostek samorządu terytorialnego w latach 2014 - 2016 oraz 2015 - 2017, Ministerstwo Finansów.

Na podstawie uzyskanych danych można stwierdzić, iż w 2017r. liczba miast z nadwyżką na poziomie przekraczającym kwotę $200 \mathrm{mln}$ zł uległa zwiększeniu o blisko $67 \%$ w porównaniu do roku 2014. Jednocześnie liczebność miast na prawach powiatu o najniższym poziomie nadwyżki zmniejszyła się zaledwie o $12 \%$, tj. z 44 jednostek w 2014r. do 39 w 2017r. W latach 2014-2017 najliczniejszą grupę stanowily miasta, których nadwyżka operacyjna nie przekroczyła $50 \mathrm{mln}$ zł. W 2014r. prawie $83 \%$ wszystkich miast na prawach powiatu uzyskało nadwyżkę niższą niż $100 \mathrm{mln}$ zł, natomiast w 2017 r. było to $80 \%$, co oznacza, iż w przypadku większości miast na prawach powiatu nie odnotowano znaczącej zmiany poziomu nadwyżki operacyjnej. Ostatnią analizowaną kategorią JST były województwa i poziom nadwyżki operacyjnej uzyskanej właśnie przez te jednostki (wykres 6).

W 2014r. blisko 94\% województw osiagnęło nadwyżkę na poziomie nie przekraczającym $200 \mathrm{mln}$ zł (15 jednostek), podczas gdy w 2017r. odsetek tych jednostek wynosił nieco ponad $81 \%$. Liczba jednostek $\mathrm{z}$ najwyższym poziomem nadwyżki operacyjnej przekraczającym $200 \mathrm{mln}$ zł zwiększyła się do 3 województw. W 2014r. województwem o najwyższym poziomie nadwyżki było województwo wielopolskie (ponad $218 \mathrm{mln}$ zł), zaś województwo mazowieckie wypracowało nadwyżkę przekraczająca jedynie wartość $123 \mathrm{mln}$ zł, w 2017r. to samo województwo osiagnęło najwyższy poziom nadwyżki i było to ponad $683 \mathrm{mld}$ zł.

Wartość wydatków inwestycyjnych według typów JST w latach 2014-2017 prezentuje wykres 7 . 


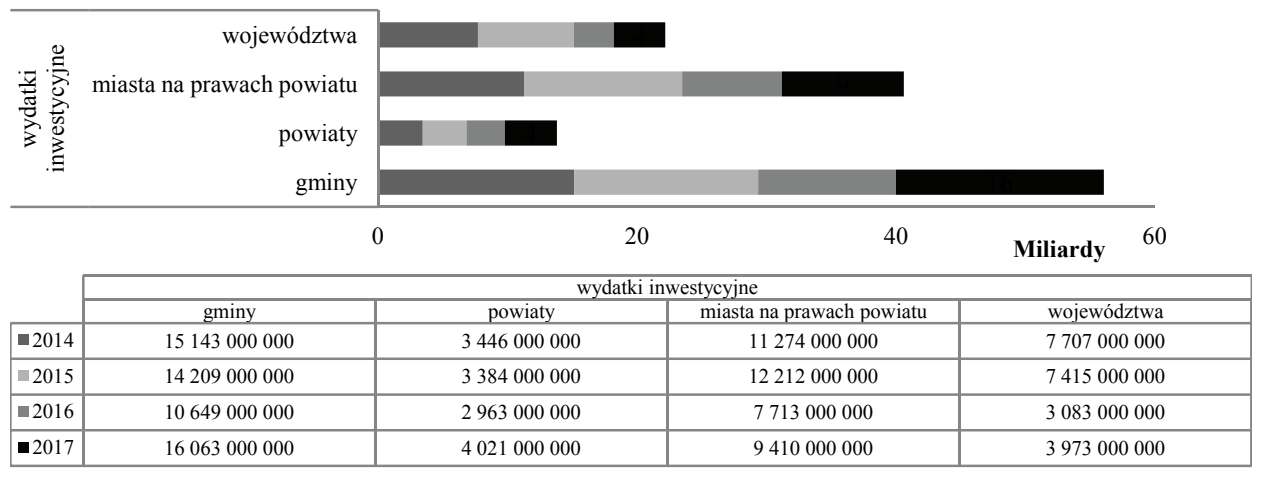

Wykres 7. Wydatki inwestycyjne według typów JST w latach 2014-2017 (mld zł)

Źródło: opracowanie własne na podstawie Informacji o nadwyżce operacyjnej jednostek samorządu terytorialnego w latach 2014 - 2016 oraz 2015 - 2017, Ministerstwo Finansów.

W prawie wszystkich typach jednostek poza gminami, odnotowano zmniejszenie poziomu wydatków inwestycyjnych w latach 2016-2017, co wynika z uruchomienia nowej perspektywy finansowej UE. Największą wartość wydatków inwestycyjnych osiagnęły gminy (w 2017r. inwestycje gmin kosztowały 16 mld zł, zaś w 2016r. było to niecałe 11 mld zł - spadek o 30\%). Najniższą wartość wydatków inwestycyjnych poniosły powiaty (niecałe 3 mld zł w 2016r. i nieco ponad 4 mld zł w 2017r.). Kolejną kategorią JST, w której odnotowano wysoki poziom wydatków inwestycyjnych były miasta na prawach powiatu. Powiaty charakteryzowała względna stabilność poniesionych wydatków inwestycyjnych. Jednak wydatki inwestycyjne miast na prawach powiatu zmniejszyły się z 11 mld zł w 2014r. do 9 mld zł w 2017r. (spadek o blisko 20\%). Województwa natomiast odnotowały spadek wartości wydatków inwestycyjnych o 50\% z poziomu 8 mld zł w 2014r. do 4 mld zł w 2017r.

Średnią wartość wydatków inwestycyjnych we wszystkich typach JST prezentuje wykres 8 .

\begin{tabular}{|c|c|c|c|c|}
\hline$\gtrsim 500$ & & & & \\
\hline$\sum 300$ & & & & \\
\hline 100 & $\angle$ & 3 & 7 & \\
\hline & 2014 & 2015 & 2016 & 2017 \\
\hline 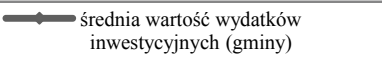 & 6312213 & 5925354 & 4440784 & 6698499 \\
\hline $\begin{array}{l}\text { średnia wartość wydatków } \\
\text { inwestycyjnych (powiaty) }\end{array}$ & 11080386 & 10846154 & 9496795 & 12887821 \\
\hline $\begin{array}{c}\text { średnia wartość wydatków } \\
\text { inwestycyjnych (miasta na prawach } \\
\text { powiatu) }\end{array}$ & 170818182 & 187876923 & 118661538 & 144769231 \\
\hline $\begin{array}{c}\text { średnia wartość wydatków } \\
\text { inwestycyjnych (województwa) }\end{array}$ & 481687500 & 463437500 & 192687500 & 248312500 \\
\hline
\end{tabular}

Wykres 8. Średnia wartość wydatków inwestycyjnych według typów JST w latach 2014-2017 (mld zł) Źródło: opracowanie własne na podstawie Informacji o nadwyżce operacyjnej jednostek samorządu terytorialnego w latach 2014 - 2016 oraz 2015 - 2017, Ministerstwo Finansów. 
Uzyskane dane wskazują iż średnia wartość wydatków inwestycyjnych jednostek samorządowych w badanym okresie była zróżnicowana w przypadku miast na prawach powiatu oraz województw, natomiast na poziomie gmin i powiatów wykazywała względną stabilność. Najwyższą średnią wartość wydatków inwestycyjnych poniosły województwa i miasta na prawach powiatu, zaś najniższą gminy i powiaty.

\section{Podsumowanie}

Przeprowadzone obliczenia i analizy wskazują, iż stabilność finansowa wszystkich typów jednostek uległa poprawie ze względu na wzrost łącznej kwoty nadwyżki operacyjnej. Jednak różna jest dynamika tego procesu na poszczególnych poziomach samorządu terytorialnego. Pomimo ogólnego wzrostu wartości nadwyżki operacyjnej wśród wszystkich typów JST, to gminy łącznie osiagały najwyższy jej poziom, a województwa najniższy. Jednak $\mathrm{w}$ przeliczeniu na jedną jednostkę to właśnie województwa miały najwyższą wartość nadwyżki operacyjnej, a gminy najniższą. Jednostki różniły się także strukturą i dynamiką zmian w obrębie kwoty nadwyżki operacyjnej. W przypadku gmin i powiatów odnotowano znaczące (blisko o połowę) zwiększenie liczby jednostek z najwyższą wartością nadwyżki operacyjnej. Analizując sytuację miast na prawach powiatu należy wskazać, iż w przypadku większości jednostek tego typu nie odnotowano znaczącej zmiany poziomu nadwyżki operacyjnej. W latach 2014-2017 najliczniejszą grupę stanowiły miasta, których nadwyżka operacyjna nie przekroczyła $50 \mathrm{mln}$ zł. Województwa natomiast odnotowały znaczącą poprawę w zakresie średniej wartości osiąganej nadwyżki operacyjnej i jednoczesny spadek wartości wydatków inwestycyjnych o blisko $50 \%$.

Analiza poniesionych wydatków inwestycyjnych wskazuje, iż w przypadku gmin odnotowano największą aktywność w tym zakresie, ponieważ łącznie była to najwyższa wartość, zaś najwyższą średnią kwotę wydatków inwestycyjnych osiagnęły województwa i miasta na prawach powiatu. W 2016r. wzrostowi średniej wartości nadwyżki operacyjnej towarzyszył jednoczesny spadek średniej wartości wydatków inwestycyjnych. W powiatach zaś wzrost stabilności finansowej mierzonej poziomem łącznej nadwyżki operacyjnej nie przełożył się na wzrost potencjału inwestycyjnego tych jednostek wyrażonego poprzez wzrost łącznej kwoty wydatków inwestycyjnych. W badanym okresie powiaty charakteryzowała względna stabilność średniej kwoty poniesionych wydatków inwestycyjnych. W przypadku wartości średnich powiaty i gminy odnotowały jednoczesny wzrost średniej wartości nadwyżki operacyjnej i średniej kwoty wydatków inwestycyjnych. Województwa i miasta na prawach powiatu mimo dynamicznego wzrostu średniej wartości nadwyżki operacyjnej nie odnotowały równie dynamicznego wzrostu średniej wartości wydatków inwestycyjnych.

Pomimo traktowania nadwyżki operacyjnej jako ważnego elementu tworzącego potencjał inwestycyjny samorządu, nie odnotowano jednakowej dynamiki realizowania działan inwestycyjnych wybranych typów samorządów przy wzroście kwoty nadwyżki operacyjnej.

\section{Bibliografia}

Alińska A., Frydrych S., Klein E.: Finanse w koncepcji zrównoważonego rozwoju. Kwartalnik Kolegium Ekonomiczno-Społecznego „Studia i Prace” Szkoły Głównej Handlowej, 1/2018 
Brol R.: Gospodarka lokalna i regionalna w teorii i praktyce, Wydawnictwo Akademii Ekonomicznej im. Oskara Langego, Wrocław 2004

Cichocki K.S.: Wieloletnie planowanie finansowe: ocena zdolności kredytowej w gminie, najtańszy pieniądz we właściwym czasie, Wyd. MUNICIPIUM, Warszawa 2001

Dochody jednostek samorządu terytorialnego 2004-2012. Perspektywa 2013-2020. Senat RP, Związek Miast Polskich, Warszawa 2013

Dworakowska M.: Determinanty rozwoju aktywności inwestycyjnej miast na prawach powiatu, Wydawnictwo Uniwersytetu w Białymstoku, Białystok 2013

Filipiak B., M. Tarczyńska-Łuniewska: Potencjał jednostki samorządu terytorialnego - próba systematyzacji pojęciowej i metodycznej, „Finanse Komunalne” 1-2/2016

Filipiak B.: Podatkowe czynniki kształtujące potencjał finansowy jednostek samorządu terytorialnego, „Finanse, Rynki Finansowe, Ubezpieczenia” 1/2016

Filipiak B.: Wykorzystanie statystyki publicznej do oceny stabilności finansowej jednostek samorządu terytorialnego, „Wiadomości Statystyczne” 11/2016

Financial Management in a Local Government Association (LGA). Netherlands Ministry of Foreign Affairs, VNG International, 2014

Gubernat-Ulatowski E.: Potencjał finansowy i inwestycyjny a aktywność inwestycyjna jednostek samorządu terytorialnego, „Studia Ekonomiczne” Zeszyty Naukowe Uniwersytetu Ekonomicznego w Katowicach 294/2016

Hok B.: Wybrane czynniki finansowe do oceny zamożności jednostek samorządu terytorialnego na przykładzie gmin wiejskich i miejsko-wiejskich województwa zachodniopomorskiego, Zeszyty Naukowe Wydziału Nauk Ekonomicznych Politechniki Koszalińskiej 20/2016 Improving Financial Sustainability for Local Government, www. walga.asn.au Indicators of Financial Condition In Public Sector Statements of Recommended Practice (SORP), CICA,Toronto, ON, Canada 2009.

Informacja o nadwyżce operacyjnej jednostek samorządu terytorialnego w latach 2014 - 2016, 2015-2017, Ministerstwo Finansów,www.finanse-

arch.mf.gov.pl/budzetpanstwa/finansesamorzadow/

Jastrzębska M.: Polityka budżetowa jednostek samorządu terytorialnego, Wyd. Uniwersytetu Gdańskiego, Gdańsk 2005.

Klank L., Stabilność finansowa jednostek samorządu terytorialnego, „Przedsiębiorczość i Zarzadzanie" 9/2014.

Lubińska T., Franek S., Będzieszak M.: Potencjał dochodowy samorządu w Polsce, Difin, Warszawa 2008.

Mackiewicz M., Malinowska-Misiag E., Misiag W., Tomalak M.: Ramy finansowe strategii rozwoju województw na lata 2007-2013, Instytut Badań nad Gospodarką Rynkową, Warszawa 2006.

Ministerstwo Finansów: Wskaźniki do oceny sytuacji finansowej jednostek samorządu terytorialnego w latach 2014-2016, www.finanse.mf.gov.pl/documents/766655/6146149/III+_Wsk+2014-2016_opis.pdf

Navarro-Galera A., Rodriquez-Bolivar M.P., Alcaide-Munoz L., Lopez-Subires M.D.: Measuring the financial sustainability and it's influential factors in local governments, „Applied Economics” 41/2016.

Ocena efektywności zarządzania długiem lokalnym w Polsce na przykładzie miast na prawach powiatu, Zeszyty Naukowe Polskiego Towarzystwa Ekonomicznego w Zielonej Górze 9/2018

Pedro Rodríguez Bolívar M., Navarro Galera A., Alcaide Muñoz L., Deseada López Subires M.: Analyzing Forces to the Financial Contribution of Local Governments to Sustainable Development, MDPI, Sustainability 8/2016.

Pietrzak B.: Nowe spojrzenie na stabilność systemu finansowego - mechanizmy pomocy finansowej. „Studia i Prace” Kolegium Zarządzania i Finansów SGH, 155/2017.

Poniatowicz M.: Stabilność finansowa jednostek samorządu terytorialnego w aspekcie nowej perspektywy finansowej Unii Europejskiej i zmian w systemie dochodów samorządowych. „Ekonomiczne Problemy Usług” 125/2016. 
Raport o stabilności systemu finansowego, Departament Stabilności Finansowej NBP. Warszawa 2018.

Recomended Practice Guideline. Reporting on the Long-Term Sustainability of an Entity's Finances, International Public Sector Accounting Standards, International Federation of Accountants, New York 2015.

Reporting on the Long-Term Sustainability of a Public Sector Entity's Finances; IFAC, Canada 2012.

Shiller R.: Finance and the good society. Princeton University Press, Princeton 2012.

Swianiewicz P., Nadwyżka operacyjna, http://www.wspolnota.org.pl,

Wiewióra M.,2008, http://www.samorzad.pap.pl/palio/html.run? Instance $=\mathrm{cms}$ samorzad. pap.pl\&_PageID $=2 \& s=$ depesza\&dz=lewa_szpalta.wolters\&dep $=45334 \&$ data $=\&$ _CheckSum $=177$ 4212395

Wiewióra M.: Wpływ nadwyżki operacyjnej budżetu na kondycję finansową jednostki samorządu terytorialnego, „Samorząd Terytorialny” 11/2008.

Wojciechowski M.: Kierunki racjonalizacji gospodarki finansowej samorządu terytorialnego, Zeszyty Naukowe Wyższej Szkoły Bankowej w Poznaniu 2/2017.

Wosiek M.: Regionalne zróżnicowanie sytuacji finansowej gmin w warunkach dysproporcji rozwojowych w Polsce. „Nierówności społeczne a wzrost gospodarczy” 34/2013.

Wójtowicz K.: Podział zadań publicznych między państwo a samorząd a problem zapewnienia stabilności fiskalnej jednostek samorządu terytorialnego. „Nierówności Społeczne a Wzrost Gospodarczy", 40/2014.

Wójtowicz K.: Znaczenie wybranych czynników ekonomiczno-społecznych dla kształtowania stabilności fiskalnej gmin miejskich w Polsce, Folia Oeconomica Acta Universitatis Lodziensis $2 / 2018$.

\section{Abstract}

This article aims to assess the level of operating surplus as an indicator determining the financial stability of local governments, and to show the amount of financial expenses that prove the investment potential of the government entity. The following methods were used: literature analysis, analysis of budget indicators (income and current expenses, financial expenditure, operating result) and methods of descriptive statistics. The analysis adopted financial data of all types of local government units in Poland: 16 voivodships, 314 poviats and 2478 communes for the years 2014-2017. The conducted analysis allowed for a positive verification of the hypothesis, according to which the operating surplus determines both the level of financial stability and the level of local government units' investment potential.

Key words: financial stability, financial potential, investment potential, operating surplus.

JEL Code: R 50, R 51, H 72.

Informacje o autorach:

dr Agnieszka Cyburt

e-mail: a.cyburt@wp.pl

ORCID:0000-0002-7084-6066

dr Agnieszka Galecka

e-mail: agalecka.plejada@op.pl

ORCID: 0000-0002-7603-8086

Państwowa Szkoła Wyższa im. Papieża JP II w Białej Podlaskiej

Katedra Ekonomii i Zarządzania 